\title{
MODEL PROJECT BASED LEARNING UNTUK MENINGKATKAN KETERAMPILAN MENULIS SEJARAH WANITA PADA MAHA- SISWA
}

\author{
Yeni Wijayanti \\ Universitas Galuh Ciamis
}

\begin{abstract}
Abstrak: Pembelajaran sejarah yang menyenangkan dengan membuat kreasi media sangat diperlukan agar motivasi siswa dalam belajar tinggi. Tulisan ini diharapkan mampu memberikan sumbangan pemikiran terhadap pengembangan ilmu kependidikan terutama yang menyangkut permasalahan yang ditemui dalam pembelajaran sejarah yang kontekstual, khususnya yang berkaitan dengan sejarah lokal, sehingga siswa mendapatkan pemahaman yang lebih mendalam, pembelajaran yang menyenangkan, dan prestasi yang lebih baik. Metode yang digunakan adalah Research and Development $(R \& D)$. Untuk meningkatkan prestasi belajar dan kesadaran sejarah siswa maka dikembangkanlah media video situs Kerajaan Galuh yang telah dilakukan uji internal (validasi). Hasil eksperimen menunjukkan bahwa media video/audio visual situs sejarah Kerajaan Galuh efektif untuk meningkatkan kesadaran sejarah siswa.
\end{abstract}

Kata-kata kunci: Audio Visual, Situs, Kesadaran Sejarah.

\begin{abstract}
Joyfull teaching of history by making media creation is very important to increase student's learning motivation. This paper is expected to contribute towards the development of educational science, concerning to the problems encountered in the contextual learning of history, with regards to local history, therefore students gain a deeper understanding, fun learning, and better performance. This paper used a Research and Development $(R \& D)$ method. To improve learning achievement and student's historical awareness is developed by video media of Galuh Kingdom sites has been validated. The experimental results showed that the media of video/audio visual about historical sites of Galuh Kingdom is effective to increase the student's historical awareness
\end{abstract}

Keywords: audio visual, site, historical awareness.

Kesadaran sejarah mempunyai arti penting dalam pembentukan kepribadian individu/masyarakat dan kepribadian ini akan menciptakan sebuah identitas dari individu atau masyarakat tersebut. Hal ini tentunya tidak akan terlepas dari akarnya yaitu, sejarah. Proses pembentukan kesadaran sejarah ini menunjukkan ada hubungan antara sejarah dan pendidikan. Sejarah tidak akan berfungsi bagi proses pendidikan yang menjurus ke arah pertumbuhan dan pengembangan karakter bangsa, apabila nilai-nilai sejarah tersebut belum terwujud dalam pola-pola perilaku yang nyata.

Pendidikan, yang berorientasi pada pengetahuan yang ditanamkannya, kapasitas berpikir yang dikembangkannya, dan berbagai kegiatan praktis yang dijalankannya, dapat menjadi instrumen yang potensial untuk membentuk kepribadian masyarakat melalui kesadaran sejarah yang ditanamkan di lingkungan sekolah. Sejarah selain memberi pengetahuan faktual juga membangkitkan perasaan sejarah (historical sense). Seiring dengan kemajuan ilmu pengetahuan dan 
teknologi serta perubahan zaman, yang berdampak pada kehidupan manusia, maka perlu dilakukan terobosan-terobosan baru di dalam mengatasi permasalahan pendidikan.

Dalam hal ini, guru harus mampu mengembangkan materi dan media pembelajaran agar siswa dapat lebih tertarik untuk belajar sejarah serta tujuan dari pembelajaran dapat tercapai. Pengembangan yang dilakukan oleh guru tentu saja harus selaras dengan kurikulum yang diberlakukan.

Ciamis merupakan salah satu kabupaten di Jawa Barat yang memiliki situs bersejarah yang berkaitan dengan Kerajaan Galuh. Saat ini peninggalan Kerajaan Galuh menjadi benda cagar budaya yang dilindungi oleh pemerintah dan menjadi salah satu potensi wisata yang terdapat di Ciamis.

Untuk memudahkan guru dalam menyampaikan informasi tentang peristiwa sejarah yang terjadi di lingkungan peserta didik tersebut, guru memanfaatkan peninggalan sejarah Kerajaan Galuh berupa situs yang ada di Ciamis sebagai media pembelajaran sejarah dalam bentuk audio visual/video. Media video ini dirasa tepat dan efektif dalam membantu guru memberikan informasi tentang peristiwa sejarah yang terjadi, mengingat situsnya tersebar di berbagai titik di Kabupaten Ciamis, hal ini tentunya memakan banyak waktu dan tenaga untuk mengunjunginya. Namun dengan video yang dikembangkan dan dibuat oleh guru, siswa tidak perlu lagi mengunjungi situs besejarah itu secara langsung untuk mempelajari peristiwa sejarah yang ada di baliknya, tetapi cukup hanya mengamati tayangan video di kelas serta membahas konsep-konsep yang berkaitan dengan peristiwa sejarah tersebut.

\section{PROSES PEMBELAJARAN SEJARAH DI SMA NEGERI 1 CIAMIS}

Kegiatan pembelajaran merupakan suatu proses untuk melakukan perubahan, tentunya proses pembelajaran itu secara sadar atau tidak sebenarnya dapat berlangsung di mana saja dan kapan saja. Sekecil apapun perubahan yang kita capai sudah dapat dikatakan sebagai suatu proses pembelajaran, baik itu berupa perubahan yang positif maupun yang bersifat negatif bagi si pembelajar. Hal ini terjadi tentunya tidak terlepas dari apa yang disebut dengan Rencana Pelaksanaan Pembelajaran (RPP), silabus, serta metode atau model.

Pembelajaran sejarah yang selama ini berlangsung di SMAN 1 Ciamis adalah ceramah, diskusi kelompok yang dikombinasikan dengan games/permainan. Guru memanfaatkan media power point untuk membantu dan mempermudah dalam penyampaian materi. Guru juga menggunakan buku teks yang sudah tersedia. Ceramah merupakan sebuah bentuk interaksi melalui penerangan dan penuturan lisan dari pendidik kepada peserta didik.

Metode ceramah sebenarnya metode yang bagus jika penggunaannya betul-betul disiapkan dengan baik dan didukung alat dan media, serta memperhatikan batas-batas penggunaannya. Hal yang paling penting untuk diperhatikan dalam metode ceramah adalah isi ceramah mudah dipahami dan diterima serta mampu menstimulasi pendengar (peserta didik) untuk mengikuti dan melakukan sesuatu yang terdapat dalam ceramah. Sebenarnya metode ceramah merupakan metode yang sampai saat ini sering digunakan oleh pendidik. Hal ini selain disebabkan beberapa pertimbangan tertentu, juga karena adanya faktor kebiasaan baik dari pendidik maupun peserta didik. Pen- 
didik biasanya belum puas dalam proses pengelolaan pembelajaran jika tidak melakukan ceramah. Demikian juga dengan peserta didik mereka akan belajar jika ada pendidik yang memberikan materi pelajaran melalui ceramah sehingga timbul persepsi jika ada pendidik yang memberikan ceramah berarti ada proses pembelajaran, sedangkan jika tidak ada pendidik berceramah berarti tidak ada proses pembelajaran.

Selain metode ceramah yang digunakan dalam proses pembelajaran sejarah di SMAN 1 Ciamis, guru juga menggunakan metode diskusi. Menurut Nunuk Suryani dan Leo Agung, metode diskusi adalah penyajian pelajaran dengan mengemukakan suatu permasalahan, dan peserta didik diharapkan untuk membahas dan memecahkannya. Diskusi pada dasarnya ialah tukar menukar informasi dan pendapat, dengan maksud untuk mendapat pengertian bersama yang lebih jelas tentang sesuatu (Suryani dan Leo Agung, 2012:57). Tujuan utama metode diskusi ini adalah untuk memecahkan suatu permasalahan, menjawab pertanyaan, menambah dan memahami pengetahuan siswa, serta untuk membuat suatu keputusan (Majid, 2013:200).

Kendala yang sering dihadapi guru dalam pembelajaran sejarah di sekolah yakni materi pembelajaran sejarah sangat padat dan banyak, sehingga tidak semua materi yang disampaikan kepada siswa dapat diingat dan dipahami dengan baik, maka perlunya sebuah media pembelajaran untuk memberikan dampak positif dalam pembelajaran sejarah seperti memudahkan penguasaan dan pemahaman terhadap materi sejarah yang disampaikan serta memecahkan kebosanan peserta didik terhadap pembelajaran sejarah. Belajar dengan menggunakan indera ganda (pandang dan dengar) akan memberikan keuntungan bagi siswa. Siswa akan belajar lebih banyak dari pada jika materi pelajaran disajikan hanya dengan stimulus pandang atau hanya dengan stimulus dengar saja, hal ini sesuai dengan pandangan Dale (dalam Arsyad, 2013:13) yang menggambarkan hasil belajar melalui indra pandang dan dengar sangat menonjol perbedaannya. Dale memperkirakan bahwa perolehan hasil belajar melalui indera pandang sekitar $75 \%$, melalui indera dengar $13 \%$, dan melalui indera lainnya sekitar $12 \%$. Maka dengan adanya media pembelajaran yang dilihat, didengar kemudian diamati sekaligus akan memberikan pemahaman siswa terhadap materi yang diajarkan, sehingga menjadikan pembelajaran yang menyenangkan.

Hasil dari penelitian pendahuluan memperlihatkan bahwa guru memiliki keinginan besar untuk menggunakan dan mengembangkan sebuah media pembelajaran yang baik, yang mampu merangsang otak siswa untuk menumbuhkan kreativitas, meningkatkan minat siswa dalam mengikuti pembelajaran sejarah. Akan tetapi ditemui beberapa kendala yang dihadapi antara lain: waktu luang untuk menyusun atau membuat media pembelajaran. Tidak dimanfaatkannya media dalam proses pembelajaran pada umumnya disebabkan oleh berbagai alasan, seperti waktu persiapan mengajar terbatas, sulit mencari media yang tepat, biaya tidak tersedia, atau alasan lain. Guru sebagai pelaku pembelajaran di kelas, dihadapkan pada persoalan tentang bagaimana memberikan materi pembelajaran kepada siswa agar dengan mudah dapat diterima dan dimengerti siswa.

Penggunaan media sebenarnya sangat membantu siswa baik untuk menyerap materi maupun untuk memotivasi belajar siswa. Oleh karena itu, guru perlu meningkatkan 
kapasitasnya untuk membuat media pembelajaran. Media pembelajaran dapat menambah kemenarikan tampilan materi sehingga meningkatkan motivasi dan minat serta mengambil perhatian peserta didik untuk fokus mengikuti materi yang disajikan, sehingga diharapkan efektivitas belajar akan meningkat pula. Media pembelajaran juga merangsang peserta didik untuk berfikir kritis, menggunakan kemampuan imajinasinya, bersikap dan berkembang lebih lanjut, sehingga melahirkan kreativitas dan karya-karya inovatif. Hal ini sejalan dengan Sadiman (2012: 17), yang menilai bahwa dalam proses belajar mengajar, media mempunyai kegunaan yang penting, seperti: memperjelas penyajian pesan agar tidak terlalu verbalistis; mengatasi keterbatasan ruang, waktu, dan daya indera; dapat mengatasi sikap pasif siswa karena menimbulkan kegairahan belajar; dapat mengatasi kesulitan guru dalam penyesuaian antara kurikulum dengan siswa karena memberi rangsangan yang sama. Hamalik (1994) juga mempertegas bahwa penggunaan media pembelajaran dalam proses belajar mengajar dapat membangkitkan keinginan dan minat baru siswa, membangkitkan motivasi dan rangsangan kegiatan belajar dan bahkan membawa pengaruh psikologis terhadap siswa.

Dari perspektif siswa mengungkapkan bahwa selama ini mereka hanya belajar berdasarkan buku teks pada setiap kali pertemuan, hal ini membuat siswa tidak mempunyai ketertarikan terhadap materi yang diajarkan dan jika terkadang mengandalkan power point, siswa juga tidak paham terhadap materi yang diajarkan karena isi dari power point tersebut juga sama dengan yang ada di buku pegangan siswa, tidak ada video/gambar/ film/contoh yang ditampilkan pada power point tersebut, sehingga media tersebut menjadi tidak begitu berperan dalam proses pengembangan kognitif siswa. Dengan adanya audio visual/video situs sejarah Kerajaan Galuh ini yang digunakan sebagai media dan sumber belajar, selain dapat mengembangkan kognitif siswa, media audio visual/video situs sejarah Kerajaan Galuh ini diharapkan juga bisa mengangkat kecerdasan afektif siswa yaitu sikap kesadaran sejarah. Siswa dapat melihat dengan nyata peninggalan Kerajaan Galuh yang ada di sekitar siswa, kemudian siswa diharapkan dapat menganalisis berpikir kritis tentang wujudwujud akulturasi Hindu Budha yang terlihat dari peninggalan yang ada di situs Karangkamulyan dan Astana Gede. Melalui tayangan audio visual situs Kerajaan Galuh inilah diharapkan dapat meningkatkan kesadaran sejarah siswa.

Beberapa temuan hasil pada penelitian pendahuluan akan memberikan gambaran kekuatan dan kelemahan pada pembelajaran sejarah, sekaligus menjadi dasar pemikiran untuk mengembangkan media pembelajaran yang menarik perhatian siswa, mampu mengembangkan kognitif siswa, memudahkan pemahaman siswa dalam pembelajaran sejarah, menghilangkan kebosanan, melatih guru untuk mengambangkan ide pemikirannya dalam membuat media pembelajaran dan melatih guru untuk bisa membuat media pembelajaran yang menarik. Hal ini sejalan dengan pernyataan Hamalik dalam Sukiman (2012:41) bahwa pemanfaatan media dalam pembelajaran dapat membangkitkan keinginan dan minat baru, meningkatkan motivasi dan rangsangan kegiatan belajar, dan bahkan berpengaruh secara psikologis kepada peserta didik. Maka dikembangkanlah media audio visual situs sejarah Kerajaan Galuh dalam pembelajaran 
sejarah untuk meningkatkan kesadaran sejarah.

\section{PENGEMBANGAN MEDIA PEM- BELAJARAN AUDIO VISUAL SITUS KERAJAAN GALUH DALAM PEM- BELAJARAN SEJARAH DI SMAN 1 CIAMIS}

Situs sejarah Kerajaan Galuh penting karena dalam rangka pembelajaran sejarah masa Hindu-Budha. Apabila siswa harus melihat langsung ke tempat-tempat tersebut akan membutuhkan waktu yang lama, biaya yang cukup mahal karena letaknya berjauhan. Akan tetapi, jika materi ini dibuat dengan kreasi media audio visual, tentunya waktu yang diperlukan untuk belajar lebih efektif dan tidak memerlukan biaya kunjungan ke lokasi.

Dalam proses pengembangan, tentunya spesifikasi yang dihasilkan adalah media pembelajaran audio visual situs sejarah Kerajaan Galuh. Hal ini disari dari analisis kebutuhan siswa dan guru bahwa dalam proses kegiatan pembelajaran yang berlangsung selama ini masih didominasi oleh kegiatan ceramah dan diskusi kelompok. Hal ini berakibat kurangnya pemahaman yang diserap siswa, kreativitas dan daya nalar kritis siswa. Untuk meminimalisir masalah tersebut, maka peneliti memberikan terobosan dalam pembelajaran sejarah dengan mengembangkan media audio visual situs sejarah Kerajaan Galuh. Pengembangan media ini disusun setelah mengetahui kebutuhan dan karakteristik siswa.

Kerangka teoretis yang digunakan dalam pengembangan media audio visual situs sejarah Kerajaan Galuh adalah pembelajaran sejarah yang mengacu pada filosofi konstruktivisme. Dimana siswa akan membangun pengetahuan atau memahami sejarah melalui pengalaman sendiri melalui membaca, mendengar, bertanya, menelusuri, dan bereksperimen. Maka dalam pandangan konstruktivisme ini peserta didik diharapkan memiliki kemampuan berfikir untuk mengembangakan pengetahuan mereka lalu menyelesaikan setiap persoalan yang mereka hadapi dengan menghubungkan pada pengetahuan yang telah mereka pahami.

Pertama, media pembelajaran merupakan salah satu sumber belajar yang digunakan untuk melatih siswa mengkonstruksi atau mengembangkan pemikirannya dari materi yang ditangkap pada media pembelajaran tersebut kemudian mengimplementasikan atau menghubungkan ke dalam kehidupan mereka. Seperti media audio visual yang memanfaatkan situs sejarah Kerajaan Galuh. Media ini merupakan salah satu media pembelajaran yang bisa digunakan untuk membangun pemahaman siswa terhadap materi yang diajarkan sebagaimana yang dikatakan oleh Levie dan Lentz dalam Sukiman (2012:38), khususnya media visual, mengemukakan bahwa media pendidikan memiliki empat fungsi yaitu: fungsi atensi, fungsi afektif, fungsi kognitif, dan fungsi kompensatoris.

Fungsi atensi media visual merupakan inti, yaitu menarik dan mengarahkan perhatian peserta didik untuk berkonsentrasi kepada isi pelajaran yang berkaitan dengan makna visual yang ditampilkan atau menyertai teks materi pelajaran. Sering kali pada awal pelajaran peserta didik tidak tertarik dengan materi pelajaran atau mata pelajaran itu merupakan salah satu pelajaran yang tidak disenangi oleh mereka sehingga mereka tidak memperhatikan. Media gambar khususnya gambar yang diproyeksikan melalui LCD dapat menenangkan dan mengarahkan perhatian mereka kepada pelajaran yang 
akan mereka terima. Dengan demikian, kemungkinan untuk memperoleh dan mengingat isi pelajaran semakin besar.

Fungsi afektif media visual dapat terlihat dari tingkat kenikmatan peserta didik ketika belajar (atau membaca) teks yang bergambar. Gambar atau lambang visual dapat menggugah emosi dan sikap peserta didik, misalnya informasi yang menyangkut masalah sosial atau ras. Fungsi kognitif media visual terlihat dari temuan-temuan penelitian yang mengungkapkan bahwa lambang visual atau gambar memperlancar pencapaian tujuan untuk memahami dan mengingat informasi atau pesan yang terkandung dalam gambar. Fungsi kompensatoris media pembelajaran terlihat dari hasil penelitian bahwa media visual yang memberikan konteks untuk memahami teks membantu peserta didik yang lemah dalam membaca untuk mengorganisasikan informasi dalam teks dan mengingatnya kembali. Dengan kata lain, media pembelajaran berfungsi untuk mengakomodasikan peserta didik yang lemah dan lambat menerima dan memahami isi pelajaran yang disajikan dengan teks atau disajikan secara verbal.

Kedua, media audio visual situs sejarah Kerajaan Galuh yang dikembangkan dengan gabungan model kooperatif, yang akan mengembangkan dan merangsang kepekaan otak dan panca indra dengan pengamatan pada objek di dalam media audio visual situs sejarah Kerajaan Galuh, serta menumbuhkan keterampilan sosial siswa melalui interaksi di dalam kelompok dan menumbuhkan daya fikir kritis siswa dalam memahami isi dari media tersebut. Implementasi media akan berpengaruh terhadap sikap kesadaran sejarah. Tujuan pembelajaran ini berdasarkan tujuan pembelajaran sejarah yang mengacu pada filosofis kontruktivisme yakni "siswa membangun sendiri pengetahuannya, di mana belajar membentuk pengetahuan, membuat makna, mempertanyakan kejelasan, bersikap kritis, mengadakan justifikasi, serta menghubungkan pengetahuan tersebut dengan permasalahan kehidupan dan upaya-upaya yang direkomendasikan untuk memecahkan masalah tersebut, di mana pembelajaran sejarah memiliki esensi dan substansi yang mendasar, berkaitan dengan memribadikan nilainilai kesejarahan kepada siswa, menjadi siswa yang lebih memiliki kepekaan sosial dan keterampilan sosial yang dapat digunakan dalam partisipasi untuk memecahkan masalah-masalah sosial yang terjadi sehari-hari serta tantangan-tantangan masa kini dan masa depan di era global.

Ketiga, dilihat dari segi karakteristik peserta didik. Salah satunya bisa dilihat dari gaya belajar peserta didik. Gaya belajar peserta, terdiri dari beberapa tipe di antaranya tipe visual (cara belajar melalui apa yang mereka lihat), pelajar auditorial (cara belajar melalui apa yang mereka dengar) serta pelajar kinestetik (cara belajar siswa lewat gerak dan sentuhan). Dari berbagai tipe gaya belajar ini, penting bagi seorang guru untuk bisa memfasilitasi siswa dalam kegiatan pembelajaran agar memberikan kemudahan peserta didik dalam memperoleh pengetahuannya. Maka salah satu yang bisa dilakukan guru adalah dengan membuat dan mengembangkan media pembelajaran audio visual dengan memanfaatkan situs sejarah Kerajaan Galuh.

Setelah analisis kebutuhan dan karakteristik siswa dilakukan maka langkah selanjutnya adalah merumuskan kompetensi dan indikator hasil belajar. Kompetensi yang terdapat pada SMA kelas X adalah Kompetensi Inti: 3. Memahami dan menerapkan penge- 
tahuan faktual, konseptual, prosedural dalam ilmu pengetahuan, teknologi, seni, budaya, dan humaniora dengan wawasan kemanusiaan, kebangsaan, kenegaraan, dan peradaban terkait fenomena dan kejadian, serta menerapkan pengetahuan prosedural pada bidang kajian yang spesifik sesuai dengan bakat dan minatnya untuk memecahkan masalah. Kompetensi Dasar: 3.8 Mengidentifikasi karakteristik kehidupan masyarakat, pemerintahan dan kebudayaan pada masa kerajaan-kerajaan Hindu-Buddha di Indonesia dan menunjukkan contoh bukti-bukti yang masih berlaku pada kehidupan masyarakat Indonesia masa kini.

Langkah selanjutnya dari tahap perencanaan adalah merumuskan butir-butir materi, Pada penelitian ini, selain melakukan pengembangan media pembelajaran dalam bentuk slide pembelajaran sejarah yang dimuat dalam $\mathrm{CD}$, juga dilakukan pengembangan materi pembelajaran sejarah dengan mengaitkan sejarah Kerajaan Galuh, dengan materi "Wujud akulturasi budaya Hindu Budha". Dalam mengembangkan materi, dikumpulkanlah berbagai bahan bacaan yang berkaitan dengan sejarah Kerajaan Galuh dan wujud akulturasi budaya Hindu Budha yang ada di situs Kerajaan Galuh.

Kemudian langkah selanjutnya dalam tahap perencanaan adalah merumuskan alat pengukuran keberhasilan. Dalam penelitian ini, alat pengukur tingkat keberhasilan siswa terdiri dari tes objektif (untuk mengukur prestasi), dan pengisian angket skala sikap oleh siswa untuk mengetahui tingkat kesadaran sejarah siswa, serta hasil pengamatan/observasi dalam kegiatan pembelajaran.

Tahap terakhir dari perencanaan pengembangan media pembelajaran sejarah adalah pembuatan naskah program media.
Naskah dibuat berdasarkan materi yang akan diajarkan kepada siswa yang dituangkan dalam bentuk slide. Fungsi dari pembuatan naskah ini adalah sebagai penuntun dalam membuat bahan presentasi untuk mengambil gambar serta merekam suara yang relevan dengan materi yang diajarkan. Untuk kepentingan pembuatan slide, dikumpulkanlah data berdasarkan naskah yang telah dibuat, baik berupa tulisan dari uraian materi yang telah dibuat, foto, video dan musik pengiringnya serta suara sebagai narasi yang direkam. Selanjutnya setelah tahap perencanaan selesai, dilakukanlah produksi media. Tahap produksi dilakukan dengan memasukkan materi yang telah disusun dalam storyboard ke dalam komputer. Data yang dihasilkan selanjutnya diintegrasikan dengan program Windows Movie Maker. Setelah semua proses tersebut selesai maka langkah selanjutnya memasukkannya ke dalam hardisk dan CD. CD itulah nantinya yang dijadikan sebagai media pembelajaran sejarah

Untuk mengevaluasi media pembelajaran video yang telah di produksi maka dilakukan validasi oleh ahli materi dan media pembelajaran, uji coba masing-masing terhadap 3 siswa, uji coba kelompok kecil pada 12 siswa, dan uji coba lapangan pada satu kelas yakni 30 siswa.

Analisis data oleh ahli materi adalah bertujuan untuk mengetahui kelayakan media yang akan diterapkan dalam proses pembelajaran. Berdasarkan penilaian dari aspek penilaian kesesuaian isi materi dengan tujuan pembelajaran, kesesuaian materi dengan tingkat pendidikan, dan kebenaran cerita dengan sejarah dengan 3 indikator, dari ahli materi diperoleh rerata adalah 4 . Ini menunjukkan media pembelajaran yang dikembangkan mempunyai kategori "Baik". 
Hasil validasi dari ahli media dan desain pembelajaran, media pembelajaran ini secara keseluruhan dinyatakan "Baik" dan layak diterapkan dalam proses pembelajaran dengan revisi sesuai saran ahli media dan desain pembelajaran. Menurut ahli media, tayangan video secara umum sudah bagus, baik itu dilihat dari durasi, kualitas gambar dan suara. Akan tetapi, pada prolog video perlu ditambahkan tujuan dan indikator pembelajaran. Kemudian pada tampilan prasasti Kawali, tidak ditampilkan tulisan prasasti yang berbahasa Sunda. Selanjutnya pada penutup/closing, perlu ditampilkan pembelajaran yang diinginkan, yaitu menumbuhkan kesadaran sejarah. Untuk bagian paling akhir perlu disebutkan pihak-pihak yang berkontribusi terhadap pembuatan video tersebut.

Dari hasil penilaian serta saran-saran yang diberikan, maka media pembelajaran diperbaiki dengan saran dari ahli materi adalah penambahan tulisan pada lokasi situs dan musik pengiring yang sesuai dengan daerah. Dan saran dari siswa yaitu memperbaiki tampilan slide dalam tayangan agar lebih menarik.

Sedangkan saran dari ahli media dan desain pembelajaran, di antaranya menambahkan tujuan dan indikator pembelajaran, menampilkan tulisan prasasti yang berbahasa Sunda pada salah satu prasasti yang belum ada tulisannya, dan pada penutup menampilkan pembelajaran yang diinginkan, serta pihak-pihak yang terkait dalam pembuatan video.

Untuk selanjutnya media pembelajaran audio visual situs Kerajaan Galuh siap untuk diujicobakan di lapangan kelas sebenarnya dengan 30 orang siswa. Berdasarkan data hasil uji coba lapangan, secara keseluruhan dapat disimpulkan bahwa media pembelajaran menggunakan audio visual yang dikembangkan peneliti termasuk dalam kategori Baik menurut siswa.

Uji coba lapangan bertujuan untuk menentukan apakah penggunaan produk hasil pengembangan memiliki dampak yang positif terhadap kesadaran sejarah siswa yang tinggi dan untuk mengumpulkan informasi yang dapat digunakan untuk memperbaiki kualitas produk sehingga produk siap untuk diterapkan dalam kondisi yang lebih luas.

\section{EFEKTIVITAS MEDIA PEMBELAJA- RAN SEJARAH MENGGUNAKAN AUDIO VISUAL SITUS KERAJAAN GALUH DALAM MENINGKATKAN KESADARAN SEJARAH}

Uji efektivitas digunakan untuk mengetahui keberhasilan pembelajaran dengan menggunakan media audio visual Situs Kerajaan Galuh dalam meningkatkan prestasi belajar dan kesadaran sejarah di SMAN 1 Ciamis. Untuk menghitung efektivitas media pembelajaran diadakan eksperimen. Kelas X MIPA 7 dipilih sebagai kelas eksperimen dengan menggunakan media yang dikembangkan, sedangkan kelas X MIPA 6 sebagai kelas kontrol dengan menggunakan power point. Penetapan dua kelas ini dengan cara melalui uji kesetaraan. Uji kesetaraan yang digunakan adalah uji homogenitas. Nilai-nilai yang digunakan untuk uji homogenitas adalah dari nilai pre tes. Nilai-nilai tersebut kemudian dihitung menggunakan program SPSS 16.00. Setelah dikomputasikan diperoleh kesimpulan bahwa variansi-variansi dari kedua populasi tersebut sama (homogen).

Dari hasil uji efektivitas diperoleh prestasi kelompok yang menggunakan media pembelajaran audio visual Situs Kerajaan 
Galuh yang dikembangkan lebih tinggi dari pada kelompok yang menggunakan media power point. Seperti yang disampaikan Hamalik (1994: 10), pemanfaatan media pembelajaran dalam proses belajar mengajar dapat membangkitkan keinginan dan minat baru, membangkitkan motivasi dan rangsangan kegiatan belajar, bahkan membawa pengaruh psikologis terhadap siswa. Peserta didik lebih dapat memahami dan memperoleh informasi yang padat. Media pembelajaran audio visual Situs Kerajaan Galuh ini selain membantu guru untuk mempermudah dalam proses pembelajaran, juga memberikan nuansa baru dalam proses pembelajaran yang lebih menarik, inovatif, dan efisien.

Berdasarkan hasil uji $\mathrm{t}$ untuk dua sampel yang independen (independent sample t test), diperoleh $\mathrm{t}_{\mathrm{hit}}=5,804$ dibandingkan pada $t$ tab 2,015 (taraf signifikansi 5\%), sehingga dapat dikatakan bahwa $\mathrm{t}$ hit $>\mathrm{t}$ tabel atau 5,804 $>2,015$. Sehingga terdapat perbedaan yang signifikan nilai prestasi siswa antara kelas kontrol dan kelas eksperimen. Maka dengan demikian diperoleh kesimpulan bahwa terjadi keefektifan dalam penggunaan media pembelajaran audiovisual dalam pembelajaran sejarah di SMAN 1 Ciamis.

Sedangkan berdasarkan uji $\mathrm{t}$ pada angket untuk mengetahui pengaruh media pembelajaran terhadap kesadaran sejarah diperoleh hasil $t_{h i t}=5,210$. Ini lebih besar dibandingkan pada $t_{\text {tab }} 2,015$ dengan taraf signifikansi 5\%, sehingga dapat dikatakan bahwa $\mathrm{t}_{\text {hit }}>\mathrm{t}_{\text {tabel. }}$. Maka dengan demikian diperoleh kesimpulan bahwa terjadi keefektifan dalam penggunaan media pembelajaran berbasis audio-visual untuk meningkatkan kesadaran sejarah.
Pengintegrasian antara materi, kurikulum, dan media audio visual situs Kerajaan Galuh dapat membawa perubahan dalam diri siswa baik itu dari hasil belajar maupun dari skala sikap kesadaran sejarah. Hal ini sejalan dengan pendapat Penny dan Kathleen dalam penelitiannya (2011:207) yang menyebutkan adanya perubahan dalam diri siswa ke arah positif dengan diujicobakannya pola keterlibatan siswa dalam konteks integrasi kurikulum. Tujuan utama integrasi kurikulum adalah untuk mengupayakan penyatuan individu dan sosial melalui penyelenggaraan kurikulum di sekitar masalah yang signifikan dan isu-isu, kolaboratif diidentifikasi oleh pendidik dan peserta didik, tanpa memperhatikan batasan antar mata pelajaran. Integrasi kurikulum dengan melibatkan lingkungan sekitar juga menuntut pendidik agar mempunyai persiapan materi yang lebih. Persiapan guru akan berbeda pada tiap jenjang pendidikan yang berbeda pula. Semakin tinggi pendidikan, semakin banyak hal/materi yang harus dipersiapkan.

\section{SIMPULAN}

Penggunaan media yang minim dan kurang tepat dengan karakteristik siswa berdampak pada pembelajaran sejarah yang tidak menarik dan membosankan bagi siswa yang berujung pada hasil belajar sejarahnya menjadi tidak memuaskan. Hal ini dikarenakan pembelajaran tidak sesuai dengan kebutuhan siswa. Oleh karena itu dalam hal ini guru harus mampu memilih media yang tepat sesuai dengan kebutuhan siswa serta efektif dalam penggunaannya agar pembelajaran sejarah lebih menarik dan bermakna bagi siswa. Penggunaan media pembelajaran dalam mata pelajaran Sejarah di SMAN 1 Ciamis yang terbilang minim dikarenakan beberapa hambatan atau kendala dari faktor 
dalam dan faktor luar, antara lain: input peserta didik di sekolah tersebut dikatakan rendah, waktu luang yang dimiliki guru untuk menyusun sebuah media pembelajaran yang menarik tidak ada (guru terlalu sibuk), dan apabila mengajak siswa mengunjungi lokasi tempat peninggalan atau situs tidak memungkinkan karena jarak yang cukup jauh dan serta mengingat biaya.

Pengembangan media pembelajaran sejarah menggunakan media audio visual dilakukan dengan prosedur pengembangan yang dimulai dengan perencanaan yang terdiri dari; menganalisis kebutuhan dan karakteristik siswa, merumuskan kompetensi dan indikator hasil, merumuskan butir-butir materi, mengembangkan alat pengukuran keberhasilan, menulis naskah. Langkah selanjutnya diproduksilah media pembelajaran audio visual situs Kerajaan Galuh. Dalam penyusunannya memanfaatkan software windows movie maker. Kemudian media tersebut dilakukan expert judgment atau uji kelayakan oleh ahli antara lain ahli materi, ahli media dan desain pembelajaran. Produk direvisi dan produk diujikan kepada peserta didik dengan cara: uji coba masing-masing terhadap 3 siswa, uji coba kelompok kecil, dan uji coba lapangan. Uji kelayakan media pembelajaran sejarah menggunakan audio visual oleh ahli materi menyatakan produk media pembelajaran ini masuk dalam kategori Baik dan layak diterapkan dalam pembelajaran dengan revisi sesuai saran. Saran dari ahli media diantaranya adalah menambahkan tujuan dan indikator pembelajaran, menampilkan tulisan prasasti yang berbahasa Sunda pada salah satu prasasti yang belum ada tulisannya, dan pada penutup menampilkan pembelajaran yang diinginkan, serta pihak-pihak yang terkait dalam pembuatan video. Sedangkan saran dari ahli materi ada- lah penambahan tulisan pada lokasi situs dan musik pengiring yang sesuai dengan daerah. Dan saran dari siswa yaitu memperbaiki tampilan slide dalam tayangan agar lebih menarik

Dari peserta didik kelas eksperimen yang menggunakan media pembelajaran yang dikembangkan diperoleh skor rata-rata 81,33. Sedangkan peserta didik pada kelas kontrol yang menggunakan media power point diperoleh skor rata-rata 66,67. Berdasarkan hasil uji $\mathrm{t}$, diperoleh $\mathrm{t}_{\text {hit }}=5,804$ dibandingkan pada $\mathrm{t}$ tab 2,015 (taraf signifikansi 5\%), sehingga dapat dikatakan bahwa $\mathrm{t}_{\text {hit }}>\mathrm{t}_{\text {tabel }}$ atau 5,804 $>2,015$. Dari hasil nilai rerata dan uji t tersebut dapat disimpulkan bahwa kelompok yang menggunakan media pembelajaran yang dikembangkan mempunyai prestasi belajar yang signifikan dibandingkan dengan kelompok yang tidak menggunakan media audio visual.

Dari hasil uji $\mathrm{t}$ terhadap angket kesadaran sejarah dapat disimpulkan bahwa H0 ditolak. Hal ini diketahui dari nilai sig 0,000 sehingga kurang dari 0,05. Maka dapat disimpulkan terdapat perbedaan pengaruh terhadap kesadaran sejarah siswa antara kelas eksperimen (kelas X MIPA 7) dan kelas kontrol (kelas X MIPA 6). Jika dengan menggunakan kriteria penelitian koefisien $t_{\text {hit }}$ lebih besar dari koefisien $t_{\text {tab }}$ maka hasil yang diperoleh adalah $t_{\text {hit }}=5,210$ dibandingkan pada $t_{\text {tab }}$ 2,015 (taraf signifikansi 5\%), sehingga dapat dikatakan bahwa $\mathrm{t}_{\text {hit }}>\mathrm{t}$ tabel atau 5,210 > 2,015. Maka dengan demikian diperoleh kesimpulan bahwa terjadi keefektifan dalam penggunaan media pembelajaran berbasis audio-visual dalam pembelajaran sejarah untuk peningkatan kesadaran sejarah di SMAN 1 Ciamis. 


\section{DAFTAR RUJUKAN}

Agung S, L, Sariyatun, \& Joebagjo, H. 2012. "Pengembangan Model Pembelajaran Sejarah SMA Berbasis Pendidikan Karakter di Solo Raya". Laporan Penelitian Hibah Bersaing. Surakarta: UNS.

Agung, L dan Sri Wahyuni. 2013. Perencanaan Pembelajaran Sejarah. Yogyakarta: Ombak

Aman. 2011. Model Evaluasi Pembelajaran Sejarah. Yogyakarta: Ombak.

Arsyad, Azhar. 2013. Media Pembelajaran. Jakarta: Rajagrafindo Persada

Bishop, P.A dan Kathleen Brinegar. "Student Learning And Engagement In The Context Of Curriculum Integration". Middle Grades Research Journal. Winter 2011. Vol 6.4. hal. 207.

Daliman, A. 2012. Manusia dan Sejarah. Yogyakarta: Ombak

Daniel, D. "Teaching Students How to Research the Past: Historians and Librarians in the Digital Age". The History Teacher. February 2012. Vol 45 Number 2.

Fountain, G , Harcourt, M \& Sheehan, M. "Historical Significance And Sites Of Memory". Set: Research Information for Teachers (Wellington). May 2011, hlm. 26.

Hamalik, O. 1994. Media Pendidikan. Bandung: Citra Adtya Bakti

Jayusman dan Purnomo, A. tanpa tahun "Pengembangan Model Pembelajaran Sejarah Berorientasi Pemahaman Makna Sejarah Sebagai Upaya Membangun
Karakter Bangsa". Jurnal Penelitian Pendidikan Volume 26 Nomor 2 (hal. 123-133). Semarang: Unnes.

Kochhar, S.K. 2008. Pembelajaran Sejarah. Jakarta: Grasindo

Kuntowijoyo. 1995. Pengantar Ilmu Sejarah. Yogyakarta: Bentang Budaya

Lubis, Herlina N, dkk. 2013. Sejarah Kerajaan Galuh. Bandung: Yayasan MSI.

Majid, A. 2013. Strategi Pembelajaran. Bandung: Remaja Rosda Karya

Sadiman, Arief S, dkk. 2012. Media Pendidikan: Pengertian, Pengembangan, dan Pemanfaatnnya. Jakarta: Raja Grafindo Persada.

Sugiyono. 2013. Metode Penelitian Kuantitatif, Kualitatif, dan $R \& D$. Bandung: Alfabeta.

Sukiman. 2012. Pengembangan Media Pembelajaran. Yogyakarta: Pedagogia

Suryani, N dan Agung, L. 2012. Strategi Belajar Mengajar. Yogyakarta: Ombak.

Suswandari. "Paradigma Pendidikan Sejarah dalam Menghadapi Tantangan Masa Depan". Cakrawala Pendidikan Jurnal Ilmiah Pendidikan. Th XXIX No I (hal. 2742).

Widja, I.G. 1991. Sejarah Lokal: Suatu Perspektif dalam Pengajaran Sejarah. Bandung: Angkasa. 